\title{
Medium Optimization for the Production of Fibrinolytic Enzyme by Paenibacillus sp. IND8 Using Response Surface Methodology
}

\author{
Ponnuswamy Vijayaraghavan and Samuel Gnana Prakash Vincent \\ International Centre for Nanobiotechnology, Centre for Marine Science and Technology, Manonmaniam Sundaranar University, \\ Rajakkamangalam, Kanyakumari District, Tamil Nadu 629 502, India
}

Correspondence should be addressed to Ponnuswamy Vijayaraghavan; venzymes@gmail.com

Received 27 August 2013; Accepted 8 October 2013; Published 9 January 2014

Academic Editors: T. Betakova, Y. Mu, and L. Ramirez

Copyright (C) 2014 P. Vijayaraghavan and S. G. Prakash Vincent. This is an open access article distributed under the Creative Commons Attribution License, which permits unrestricted use, distribution, and reproduction in any medium, provided the original work is properly cited.

Production of fibrinolytic enzyme by a newly isolated Paenibacillus sp. IND8 was optimized using wheat bran in solid state fermentation. A $2^{5}$ full factorial design (first-order model) was applied to elucidate the key factors as moisture, $\mathrm{pH}$, sucrose, yeast extract, and sodium dihydrogen phosphate. Statistical analysis of the results has shown that moisture, sucrose, and sodium dihydrogen phosphate have the most significant effects on fibrinolytic enzymes production $(P<0.05)$. Central composite design (CCD) was used to determine the optimal concentrations of these three components and the experimental results were fitted with a second-order polynomial model at 95\% level $(P<0.05)$. Overall, 4.5 -fold increase in fibrinolytic enzyme production was achieved in the optimized medium as compared with the unoptimized medium.

\section{Introduction}

Fibrin is the main protein component of the blood clot, and it is normally formed from fibrinogen by the action of thrombin (EC. 3. 4. 21.5) after trauma or injury. Accumulation of fibrin in blood vessels usually increases thrombosis, leading to myocardial infarction and other cardiovascular diseases (CVDs). A variety of fibrinolytic enzymes such as tissue plasminogen activators ( $\mathrm{t}-\mathrm{PA})$, urokinase $(\mathrm{u}-\mathrm{PA})$, and streptokinase were extensively studied and used as thrombolytic agents [1]. Although t-PA and u-PA are still widely used in thrombolytic therapy today, their expensive prices and undesirable side effects prompt researchers to search for cheaper and safer thrombolytic agents. In recent years, fibrinolytic enzymes from various sources, including microorganisms, worms, and animals, have been the subject of active researches because of their potential as novel agents in preventing or treating CVDs by dissolving fibrin blood clot $[2,3]$. The genus Bacillus from traditional fermented food is an important one among the microorganisms that have been found to produce the fibrinolytic enzymes [4]. Fibrinolytic enzymes from these food-grade microorganisms can be promising alternatives for $\mathrm{t}-\mathrm{PA}$ or streptokinase in thrombolytic therapy. Nattokinase, a potent fibrinolytic enzyme, has been reported to have a potent thrombolytic activity [5]. Based on its food origin and relatively strong fibrinolytic activity, nattokinase has advantages over other commercially used medicine, in preventative and prolonged effects, convenient oral administration, and stability in the gastrointestinal tract [6].

Many fibrinolytic enzymes have been isolated from various foods such as Korean chungkookjang [7], Chinese douche [8], soybean grits [9], and Indonesian tempeh [10]. Endophytic bacteria such as Paenibacillus produce biotechnologically important enzymes. The genus Paenibacillus was created by Ash et al. [11] to accommodate the "group 3" of the genus Bacillus. It comprises over 30 species of facultative anaerobes and endospore-forming, neutrophilic, periflagellated, heterotrophic, and low $\mathrm{G}+\mathrm{C}$ Gram-positive bacilli. The name reflects this fact; in Latin paene means almost, and therefore the Paenibacillus is almost a Bacillus. Very few studies were carried out in the optimization and characterization of 
fibrinolytic enzymes from Paenibacillus sp. Recently, Lu et al. [12] purified and characterized fibrinolytic enzymes from Paenibacillus polymyxa EJS-3.

Moreover, very few studies were reported on statistical optimization of fibrinolytic enzymes production in solidstate fermentation (SSF). Tao et al. [13] optimized process parameters for the production of fibrinolytic enzymes by Fusarium oxysporum. Compared to submerged fermentation, SSF yields more enzyme and it could reduce the production cost of the enzyme. From an industrial point of view, around $30-40 \%$ of the production cost of enzymes is estimated to account the cost of the growth medium [14]. Therefore, optimization of the fermentation process parameters in SSF through a statistical approach is important for a significant improvement in yield as well as a decrease in the production cost of the enzyme. The selection of medium components is another critical factor for the production of fibrinolytic enzymes because each microbe requires unique nutrient components and environmental conditions for its growth and the production of fibrinolytic enzymes $[9,15]$. Since wheat bran was recognized as the standard substrate for SSF, it was selected for the production of fibrinolytic enzymes.

The traditional one-at-a-time optimization strategy is simple, but it fails to locate the region of optimal response because the comprehensive effect of factors is not taken into consideration for the production of fibrinolytic enzymes [16]. The statistical experimental design provides a universal language with which experts from different areas such as academia, engineering, business, and industry can communicate for setting, performing, and analyzing experiments for research. Statistically designed experiments are more effective than other classical one-at-a-time optimization strategy because it can study many variables simultaneously with a low number of observations, saving time, and costs $[17,18]$. The statistical method such as factorial design, central composite design and response surface methodology (RSM) were frequently used to optimize the process parameters for the production of antimicrobial metabolites [19], bio-surfactants [20], and fibrinolytic enzymes [16, 21]. The main objective of this study was to optimize the process parameters by statistical approach for enhancing fibrinolytic enzymes production by Paenibacillus sp. using two-level full factorial's design followed by RSM.

\section{Materials and Methods}

2.1. Isolation of Fibrinolytic Enzymes-Producing Strain. The fibrinolytic enzymes-producing strain-IND8 was isolated from the cooked Indian rice. Samples collected were plated onto skim-milk agar plates containing $(\mathrm{g} / \mathrm{L})$ peptone 5 , yeast extract $5, \mathrm{NaCl} 1.5$, agar 15 , and skim milk 10 . These plates were incubated for $24-48 \mathrm{~h}$ at $37^{\circ} \mathrm{C}$ and a clear zone on skimmed milk hydrolysis gave an indication of proteaseproducing strains. These protease producing strains were subjected to fibrinolytic enzymes screening. Fibrinolytic enzymes production was carried out in the culture medium composed of $(\mathrm{g} / \mathrm{L})$ peptone 5 , yeast extract $5, \mathrm{NaCl} 1.5$, and Casein 10. Medium was autoclaved at $121^{\circ} \mathrm{C}$ for $20 \mathrm{~min}$ and a loopful culture of the selected organism was inoculated. Submerged fermentation was performed on a rotary shaker (150 rpm) for $48 \mathrm{~h}$ at $37^{\circ} \mathrm{C}$, in $250 \mathrm{~mL}$ Erlenmeyer flasks. The cultures were centrifuged and the supernatants were used for determination of fibrinolytic activity using a fibrin plate. The fibrin plate was composed of $1 \%(\mathrm{w} / \mathrm{v})$ agarose, $0.5 \%$ $(\mathrm{w} / \mathrm{v})$ fibrinogen, $1 \%(\mathrm{v} / \mathrm{v})$, and thrombin $(100 \mathrm{NIH}$ units $/ \mathrm{mL})$ (pH 7.4) [22]. The fibrin plate was allowed to stand for $1 \mathrm{~h}$ at room temperature to form a fibrin clot layer. Ten microliters of crude enzyme was dropped into holes and incubated for $5 \mathrm{~h}$ at $37^{\circ} \mathrm{C}$, fibrinolytic enzymes exhibited a clear zone of degradation of fibrin around the well indicating its activity. The single-strain IND8 showing the largest halo zone on the fibrin plate was selected and further identified.

2.2. $16 \mathrm{~S} r \mathrm{DNA}$ Sequencing. The genomic DNA was extracted from the cells of an $18 \mathrm{~h}$ culture using QIAGEN genomic DNA purification kit according to the manufacturer's instructions. The $16 \mathrm{~s}$ rDNA gene was amplified by PCR (Peltier Thermal Cycler Machine, USA) using the upstream (P1: ${ }^{5^{\prime}}$ AGAGTTTGATCMTGGCTAG $^{3^{\prime}}$ ) and the downstream primers (P2: ${ }^{5^{\prime}}$ ACGGGCGG TGTGTRC ${ }^{3^{\prime}}$ ) and DNA polymerase (Sigma, USA). The amplified product was sequenced and sequence comparison with the databases was performed using BLAST through the NCBI server [23]. The $830 \mathrm{bp} 16 \mathrm{~S}$ rDNA sequences of Paenibacillus IND8 strain were submitted to GenBank database under an accession number KF250416.

2.3. Assay of Fibrinolytic Enzymes Activity. The culture supernatant $(0.1 \mathrm{~mL})$ suitably diluted was mixed with $2.5 \mathrm{~mL}$ of $0.1 \mathrm{M}$ Tris- $\mathrm{HCl}$ buffer ( $\mathrm{pH} 7.8$ ) containing $0.01 \mathrm{M}$ calcium chloride. To this, $2.5 \mathrm{~mL}$ of fibrin $(1.2 \%$, w/v) was added and incubated for $15 \mathrm{~min}$ at $37^{\circ} \mathrm{C}$. The reaction was stopped by adding $5.0 \mathrm{~mL}$ of $0.11 \mathrm{M}$ trichloroaceticacid containing $0.22 \mathrm{M}$ sodium acetate and $0.33 \mathrm{M}$ acetic acid. The absorbance was measured at $275 \mathrm{~nm}$ against sample blank. A standard curve was performed using L-tyrosine. One unit of fibrinolytic activity was defined as the amount of enzyme which liberates $1 \mu \mathrm{g}$ of tyrosine per minute under the experimental conditions used.

\subsection{Fibrin Zymography and In Vitro Analysis of Blood Clot.} Fibrin zymography was carried out in 12\% SDS-polyacrylamide gel containing fibrinogen $(0.12 \%$, w/v) and $100 \mu \mathrm{L}$ thrombin $(10 \mathrm{NIH}$ units $/ \mathrm{mL})$. After electrophoresis at $4^{\circ} \mathrm{C}$, the gel was incubated in $0.05 \mathrm{M}$ sodium phosphate buffer $(\mathrm{pH}$ 7.4) containing $2.5 \%$ triton $\mathrm{X}-100$ for $30 \mathrm{~min}$ at room temperature. Further, the gel was washed with distilled water for $30 \mathrm{~min}$ and incubated in sodium phosphate buffer $(\mathrm{pH} \mathrm{7.4,}$ $0.05 \mathrm{M}$ ) for $5 \mathrm{~h}$ at $37^{\circ} \mathrm{C}$. It was stained with coomassie brilliant blue R-250 for $1 \mathrm{~h}$, after which it was destained and bands with fibrinolytic activities were visualized as the nonstained region of the gel. Clot lytic effects of fibrinolytic activities were studied with natural clot in vitro. The goat blood clot was cut into the same size, and crude fibrinolytic enzymes were added. The mixture was incubated at room temperature for $24 \mathrm{~h}$ and analyzed for its activities on fibrin blood clot [24]. 
2.5. Primary Screening of Process Parameters Based on Oneat-a-Time Strategy. In the present study, SSF was carried out using wheat bran as a substrate. SSF was carried out separately in a $100 \mathrm{~mL}$ Erlenmeyer flask containing $2.0 \mathrm{~g}(\mathrm{w} / \mathrm{w})$ of the substrate moistened with $2.0 \mathrm{~mL}$ buffer $(\mathrm{pH} 8.0,0.1 \mathrm{M})$. The contents were sterilized and inoculated with $0.2 \mathrm{~mL}$ of $18 \mathrm{~h}$ grown $(0.796 \mathrm{OD}$ at $600 \mathrm{~nm})$ culture broth under sterile conditions. The process parameters such as the fermentation period (24-96 h), pH (6.0-10.0), moisture content (60\%$140 \%)$, inoculum size $(3 \%-15 \%)$, carbon sources $(1 \%, w / w)$ (maltose, sucrose, starch, glucose, xylose, and trehalose), nitrogen sources $(1 \%, \mathrm{w} / \mathrm{w})$ (casein, yeast extract, peptone, beef extract, gelatin, and urea), and inorganic salts (ammonium chloride, sodium dihydrogen phosphate $\left(\mathrm{NaH}_{2} \mathrm{PO}_{4}\right)$, calcium chloride, sodium nitrate, disodium hydrogen phosphate $\left(\mathrm{Na}_{2} \mathrm{HPO}_{4}\right)$, ammonium sulphate, and ferrous sulphate) were evaluated. Twenty milliliters of double distilled water was added with the fermented medium and enzyme extracted as described earlier [25]. All experiments were carried out in triplicate, and average values are reported.

\subsection{Evaluation of Significant Factors Affecting Fibrinolytic} Enzymes Production by $2^{5}$ Factorial Designs. Two-level full factorial designs were carried out for screening the most significant factors affecting the fibrinolytic enzymes production by Paenibacillus IND8. Five factors, namely, sucrose (carbon source), yeast extract (nitrogen source), $\mathrm{NaH}_{2} \mathrm{PO}_{4}$ (inorganic salt), $\mathrm{pH}$, and moisture content of the medium were selected for the analysis of significant factors. Based on two-level full factorial design each factor was examined at two-levels (and + ). The other factors such as fermentation period and inoculum were kept at middle level. Two-level full factorial designs were based on the following first-order polynomial model. Consider

$$
Y=\alpha_{0}+\sum_{i} \alpha_{i} x_{i}+\sum_{i j} \alpha_{i j} x_{i} x_{j}+\sum_{i j k} \alpha_{i j k} x_{i} x_{j} x_{k}
$$

where $Y$ is the response (fibrinolytic activity). $\alpha_{i j}$ and $\alpha_{i j k}$ were the $i j$ th and $i j k$ th interaction coefficients; $\alpha_{i}$ was the $i$ th linear coefficient and $\alpha_{0}$ was an intercept.

Fibrinolytic activity assay was carried out in triplicates and the average of these experimental values was taken as response $Y$. ANOVA was used to estimate the statistical parameters and the values of "Prob $>F$ " less than 0.05 indicated that the model terms are significant. Statistical software, Design-Expert 8.0.7.0 (StatEase Inc, Minneapolis, USA), was used to design the experiment. Experimental design and results of the $2^{5}$ factorial designs were described in Table 1. The significant factors $(P<0.05)$ obtained from two-level full factorial designs were further optimized by RSM.

\subsection{Central Composite Design and Response Surface Method-} ology. Central composite design was employed in the present investigation to estimate the main effects. The factors used were sucrose, $\mathrm{NaH}_{2} \mathrm{PO}_{4}$, and moisture for enhanced fibrinolytic enzymes production. Each factor in the design was studied at five levels $(-\alpha,-1,0,+1$, and $+\alpha)$ in a set of 20 experiments that included 8 factorial, 6 axial, and 6 center points. All experiments were conducted in triplicates and the mean values of fibrinolytic activities (units/mL) were taken as the response $(Y)$. The second-order polynomial equation was employed to fit the experimental data. For a three-factor system the second-order polynomial equation is as follows:

$$
Y=\beta_{0}+\sum_{I=1}^{3} \beta_{i} X_{i}+\sum_{i=1}^{3} \beta_{i i} X_{i}^{2}+\sum_{i j=1}^{3} \beta_{i j} X_{i j}
$$

where $Y$ was the response, $\beta_{0}$ was the offset term, and $\beta_{i}, \beta_{i i}$, and $\beta_{i j}$ were the coefficients of linear terms, square terms, and coefficients of interactive terms, respectively. $X_{i}$ 's were $\mathrm{A}, \mathrm{B}$ and $\mathrm{C}, X_{i j}$ 's were $\mathrm{AB}, \mathrm{AC}$, and $\mathrm{BC}$.

Analysis of variance (ANOVA) was used to estimate the model. The values of "Prob $>F$ " less than 0.05 indicated that the model terms were significant. The fitted polynomial equation was expressed as three-dimensional surface plots to visualize the relationship between the responses and the levels of each factors used in the design. The statistical software (Design-Expert 8.0.7.0, StatEase Inc, Minneapolis, USA) was used to plot the $3 \mathrm{D}$ graphs.

2.8. Statistical Model Validation. With the help of the special features of RSM and 3D graph and perturbation plot the optimum value of the combination of the three factors (sucrose, $\mathrm{NaH}_{2} \mathrm{PO}_{4}$, and moisture) were validated. Experiments were carried out in triplicates in Erlenmeyer flask under theoretically predicted conditions to validate the model.

\section{Results and Discussion}

3.1. Bacterial Strain. Among the bacterial isolates strain IND8 was selected for this study in light of exhibiting strong fibrinolytic activities. The isolated strain was Gram-positive rods, citrate-, oxidase-, and nitrate-positive. It was negative to urea-, indole- and gelatin-hydrolysis. It hydrolyzed casein and fermented carbohydrates. The strain-IND8 was identified as Paenibacillus sp. based on its 16s rDNA sequence and designated as Paenibacillus sp. IND8. The phylogenetic tree constructed from the sequenced data by the neighborjoining method showed the detailed evolutionary relationship between the strain IND8 and other closely related Paenibacillus sp. (Figure 1).

3.2. Fibrin Zymography and In Vitro Analysis of Fibrinolytic Activities. Fibrin zymography revealed at least three major and two minor fibrinolytic proteases were determined from the crude extract (figure not shown). Fibrin clot degradation was observed within $24 \mathrm{~h}$ of incubation at room temperature $\left(30^{\circ} \mathrm{C}\right)$ in the tube containing fibrinolytic enzymes. In the saline solution suspend tubes, the blood clot remained (figure not shown). These fibrinolytic enzymes may have wide application in pharmaceutical industry. Fibrinolytic enzymes from this kind of food grade organisms could effectively prevent and treat cardiovascular diseases [26].

3.3. Initial Screening of Physical and Nutrient Factors for Statistical Optimization Process. The physical and nutrient 
TABLE 1: Experimental design and results of the $2^{5}$ fractorial design.

\begin{tabular}{|c|c|c|c|c|c|c|}
\hline Run & Sucrose & Yeast extract & $\mathrm{NaH}_{2} \mathrm{PO}_{4}$ & $\mathrm{pH}$ & Moisture & Response $(Y)$ \\
\hline 1 & -1 & 1 & -1 & 1 & 1 & 1711 \\
\hline 2 & -1 & -1 & 1 & -1 & 1 & 2169 \\
\hline 3 & 1 & 1 & -1 & 1 & -1 & 1931 \\
\hline 4 & 1 & 1 & 1 & -1 & -1 & 2297 \\
\hline 5 & -1 & 1 & 1 & -1 & 1 & 3413 \\
\hline 6 & -1 & 1 & 1 & 1 & -1 & 1244 \\
\hline 7 & -1 & -1 & -1 & -1 & 1 & 1867 \\
\hline 8 & 1 & -1 & 1 & 1 & 1 & 1995 \\
\hline 9 & 1 & 1 & 1 & 1 & -1 & 1976 \\
\hline 10 & -1 & -1 & -1 & 1 & 1 & 2873 \\
\hline 11 & 1 & -1 & 1 & -1 & -1 & 723 \\
\hline 12 & -1 & 1 & -1 & -1 & -1 & 787 \\
\hline 13 & 1 & -1 & -1 & -1 & 1 & 2681 \\
\hline 14 & 1 & -1 & -1 & -1 & -1 & 2315 \\
\hline 15 & -1 & 1 & -1 & 1 & -1 & 1400 \\
\hline 16 & 1 & -1 & 1 & 1 & -1 & 1400 \\
\hline 17 & 1 & 1 & -1 & 1 & 1 & 3514 \\
\hline 18 & 1 & 1 & -1 & -1 & 1 & 2086 \\
\hline 19 & -1 & -1 & 1 & 1 & 1 & 2535 \\
\hline 20 & 1 & -1 & -1 & 1 & 1 & 2251 \\
\hline 21 & 1 & -1 & -1 & 1 & -1 & 2910 \\
\hline 22 & 1 & 1 & -1 & -1 & -1 & 1171 \\
\hline 23 & -1 & -1 & 1 & 1 & -1 & 1345 \\
\hline 24 & -1 & 1 & 1 & 1 & 1 & 1940 \\
\hline 25 & 1 & -1 & 1 & -1 & 1 & 3331 \\
\hline 26 & -1 & -1 & 1 & -1 & -1 & 2535 \\
\hline 27 & -1 & 1 & 1 & -1 & -1 & 2544 \\
\hline 28 & -1 & -1 & -1 & 1 & -1 & 1381 \\
\hline 29 & 1 & 1 & 1 & 1 & 1 & 2123 \\
\hline 30 & -1 & -1 & -1 & -1 & -1 & 1894 \\
\hline 31 & -1 & 1 & -1 & -1 & 1 & 1995 \\
\hline 32 & 1 & 1 & 1 & -1 & 1 & 3768 \\
\hline
\end{tabular}

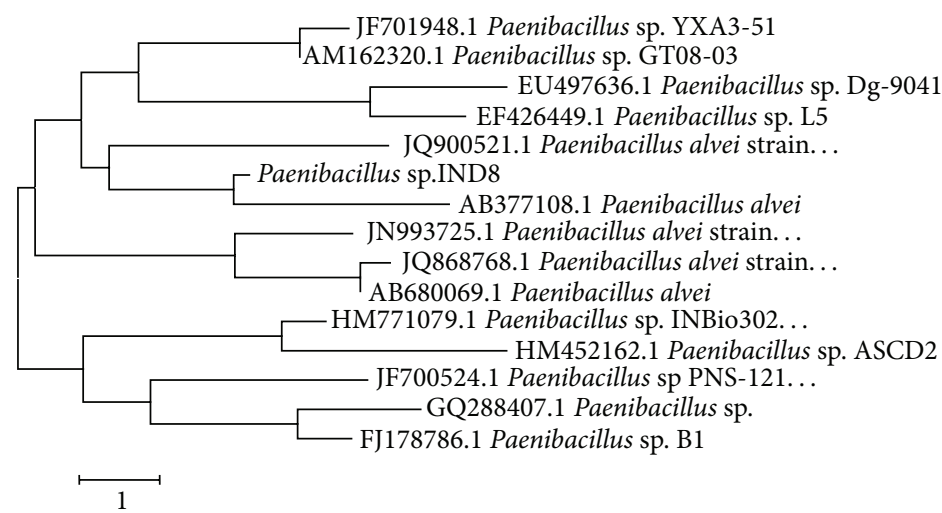

FIGURE 1: Phylogenetic relationships of stain IND8 and other closely related Paenibacillus based on $16 \mathrm{~S}$ rDNA sequence. Bar $=1$ substitution per site. 


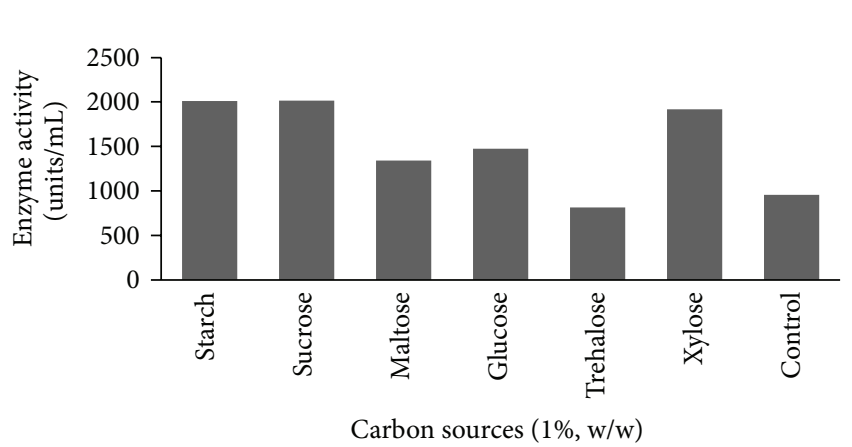

(a)

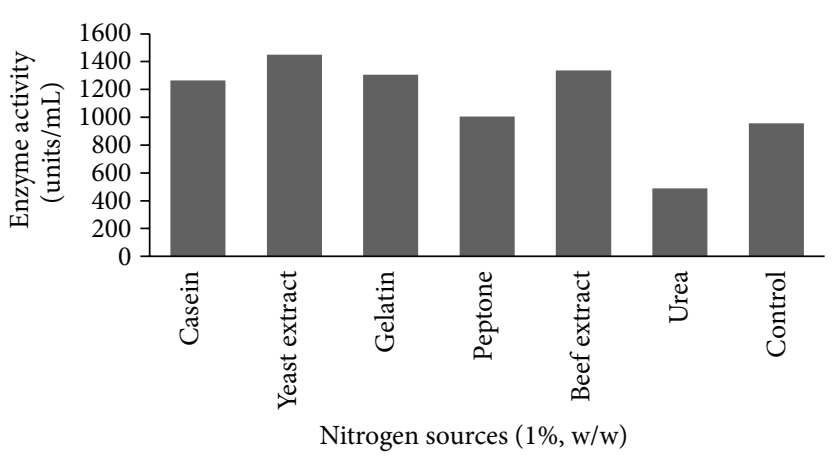

(b)

FIGURE 2: (a) Effect of different carbon sources on production of fibrinolytic enzymes. (b) Effect of different nitrogen sources on production of fibrinolytic enzymes.

factors were optimized by a traditional one-factor-at-a-time approach. In order to achieve the maximum yield of fibrinolytic enzymes, the following optimum process parameters are needed: fermentation period $(72 \mathrm{~h}), \mathrm{pH}(8.0)$, moisture (80-100\%), and inoculum (6-9\%). Among the carbon sources supplemented, sucrose supported more enzymes production (2017 units/mL) than other sources (Figure 2(a)). Among the nitrogen sources, yeast extract showed more enzymes production (1451 units/mL) (Figure 2(b)). Fibrinolytic enzymes production was high in the presence of sodium dihydrogen phosphate as the sole source of an inorganic salt (1630 units/mL). One-factor-at-a-time experiments revealed that sucrose, yeast extract, and sodium dihydrogen phosphate significantly increased fibrinolytic enzymes production. Hence, these nutrient factors were selected for statistical optimization. From the SSF point of view, moisture is one of the critical factors for enzyme production; thus it was selected for statistical optimization. The protease production by microbial strains strongly depends on the extracellular $\mathrm{pH}$ [27]. Hence, the $\mathrm{pH}$ of the medium was also considered for statistical medium optimization approach.

Conventional experimental approach used for media optimization employing "change-one-factor-at-a-time" is extremely time consuming and expensive and laborious for screening a large number of variables. Optimizing all the significant parameters by statistical experimental designs can eliminate these limitations of a single factor optimization process collectively. Several statistical designs are available such as full factorial, fractional factorial or Plackett-Burman designs, Taguchi's robust designs, and response surface methodology [28]. In this study, the important factors such as sucrose, yeast extract, $\mathrm{NaH}_{2} \mathrm{PO}_{4}, \mathrm{pH}$, and moisture were optimized by two-level full factorial designs and response surface methodology.

\subsection{Two-Level Factorial Designs on Elucidation of Medium} Components. The fibrinolytic enzymes production varied from 723 to 3768 units/mL with different combinations of the components supplemented with wheat bran. Table 1 represented the two-level full factorial designs for five selected variables (sucrose, yeast extract, $\mathrm{NaH}_{2} \mathrm{PO}_{4}, \mathrm{pH}$, and moisture) and the corresponding response for fibrinolytic enzymes production. The nutrient factors such as, sucrose, yeast extract, and $\mathrm{NaH}_{2} \mathrm{PO}_{4}$ were positively correlated and this indicated that the further increase in the concentrations of these nutrients could increase the production of fibrinolytic enzymes. Among the all nutrient and physical factors, moisture content of the medium was significantly influenced by fibrinolytic enzymes production.

Analysis of variance (ANOVA) was used to evaluate the observed results. The model $F$ value of 125.57 implied the model was significant. There is only a $0.01 \%$ chance that a "model $F$ value" this large could occur due to noise. Values of "Prob > F" less than 0.05 indicate that model terms were significant. In this model $A, C, D, E, A B, A C, A D, A E$, $\mathrm{BC}, \mathrm{BD}, \mathrm{BE}, \mathrm{CD}, \mathrm{CE}, \mathrm{DE}, \mathrm{ABC}, \mathrm{ABD}, \mathrm{ACE}, \mathrm{ADE}, \mathrm{BCD}$, $\mathrm{BCE}, \mathrm{BDE}, \mathrm{CDE}, \mathrm{ABCD}, \mathrm{ABCE}, \mathrm{ABDE}, \mathrm{ACDE}$, and ABCDE were highly significant. The correlation coefficient of this model was 0.998 . The "predicted $R$-squared" of 0.924 was in reasonable agreement with the "adjusted $R$-squared" of 0.99 . "Adequate precision" measures the signal to noise ratio. A ratio greater than 4 is desirable. In this model the ratio of 45.11 indicates an adequate signal. For $\mathrm{pH}$, the coefficient estimate was negative (-95.22) and it indicated that the reduction of $\mathrm{pH}$ could positively influence the enzymes production. Yeast extract did not influence the fibrinolytic enzymes production significantly $(P>0.05)$. Neglecting the insignificant variables, the model equation for fibrinolytic enzymes production can be written as

Enzyme activity $=+2128.28+151.22 \mathrm{~A}+80.34 \mathrm{C}-95.22 \mathrm{D}+$ $387.47 \mathrm{E}+88.28 \mathrm{AB}-158.22 \mathrm{AC}+78.22 \mathrm{AD}+51.66 \mathrm{AE}+$ $214.03 \mathrm{BC}-43.66 \mathrm{BD}+62.53 \mathrm{BE}-293.66 \mathrm{CD}+63.16 \mathrm{CE}-$ $52.78 \mathrm{DE}+46.59 \mathrm{ABC}+88.41 \mathrm{ABD}+100.34 \mathrm{ACE}-178.09 \mathrm{ADE}-$ 159.84BCD - 115.28BCE - 55.09BDE - 69.34CDE 48.28ABCD - 158.22ABCE + 204.97ABDE - 116.91ACDE 52.84ABCDE.

Enzyme production was found to be high (3768 units/ $\mathrm{mL}$ ) in the wheat bran containing $0.75 \%$ sucrose, $0.5 \%$ yeast extract, and $0.1 \% \mathrm{NaH}_{2} \mathrm{PO}_{4}$ with $100 \%$ moisture content at pH 7.0 (run 32). Wheat bran was considered as a standard substrate for the production of proteolytic enzymes and 
TABLE 2: ANOVA for selected factorial model.

\begin{tabular}{lccccc}
\hline Source & Sum of squares & df & Mean square & $F$ Value & $P$ value \\
\hline Model & $1.788 E+007$ & 27 & $6.621 E+005$ & 125.57 & 0.0001 \\
A-sucrose & $7.317 E+005$ & 1 & $7.317 E+005$ & 138.78 & 0.0003 \\
${\mathrm{C}-\mathrm{NaH}_{2} \mathrm{PO}_{4}}^{2.066 E+005}$ & 1 & $2.066 E+005$ & 39.18 & 0.0033 \\
$\mathrm{D}-\mathrm{pH}$ & $2.901 E+005$ & 1 & $2.901 E+005$ & 55.02 & 0.0018 \\
E-moisture & $4.804 E+006$ & 1 & $4.804 E+006$ & 911.14 & $<0.0001$ \\
Residual & 21091.13 & 4 & 5272.78 & & \\
Cor total & $1.790 E+007$ & 31 & & & \\
\hline
\end{tabular}

TABLE 3: Variables and their levels for response surface methodology.

\begin{tabular}{lcccccc}
\hline \multirow{2}{*}{ Variables } & \multirow{2}{*}{ Symbol } & \multicolumn{5}{c}{ Coded levels } \\
& & -1.681 & -1 & 0 & +1 & +1.681 \\
\hline Sucrose & A & 0.079 & 0.25 & 0.5 & 0.75 & 0.92 \\
$\mathrm{NaH}_{2} \mathrm{PO}_{4}$ & B & 0 & 0.01 & 0.055 & 0.1 & 0.13 \\
Moisture & $\mathrm{C}$ & 46.36 & 60 & 80 & 100 & 113.64 \\
\hline
\end{tabular}

Chang et al. [29] used wheat bran medium for the production of fibrinolytic enzymes by Bacillus subtilis IMR-NK1. The two-level full factorial designs showed that the medium containing $100 \%$ moisture showed increased fibrinolytic activities. The moisture content of the fermentation medium is one of the main factors in SSF and often determines the success of a process [30]. Based on the experimental result, yeast extract is the best choice of nitrogen source for enzyme bioprocess. These observations were in accordance with the observations made with Bacillus sp. [31].

Fibrinolytic activities were found to be high in the presence sucrose with the wheat bran medium. These results were in accordance with reported protease production in the presence of different sugars [27]. Based on the calculated $t$ values (Table 2), sucrose, $\mathrm{NaH}_{2} \mathrm{PO}_{4}$, and moisture were selected for further optimization by RSM.

3.5. Optimization by Central Composite Designs (CCD) and Statistical Analysis. CCD was used for optimization of three variables: sucrose (A), $\mathrm{NaH}_{2} \mathrm{PO}_{4}(\mathrm{~B})$, and moisture (C), each were studied at five coded levels, that is, $(-\alpha,-1,0,+1,+\alpha)$ as shown by Table 3 and the models were explained with twenty runs (Table 4 ).

In the recent years major research and development on the use of statistical methods involving various statistical software packages for the optimization studies with the aim of obtaining high yields of amylases, proteases, biosurfactants, neomycin, and so forth, [32]. Limitations and drawbacks of the single factor optimization can be eliminated by employing RSM which was used to explain the combined effects of all the factors in a fermentation process [33]. The commonly used response surface design was CCD [34] involving five levels, for each factor needed for quadratic terms to be estimable in the second-order model.

In this study the responses of the CCD were well fitted with a second-order polynomial equation.
TABLE 4: Central composite designs matrix and results on the production of fibrinolytic enzymes.

\begin{tabular}{lcccc}
\hline Run & Factor A & Factor B & Factor C & Response $(Y)$ \\
\hline 1 & 1 & -1 & -1 & 3398 \\
2 & 1 & 1 & 1 & 4008 \\
3 & 0 & 0 & 0 & 3450 \\
4 & -1.682 & 0 & 0 & 2903 \\
5 & 1.682 & 0 & 0 & 2661 \\
6 & 0 & 0 & 0 & 3360 \\
7 & -1 & 1 & 1 & 3335 \\
8 & 0 & -1.682 & 0 & 3661 \\
9 & 0 & 0 & 0 & 3808 \\
10 & 0 & 0 & 1.682 & 4418 \\
11 & 1 & 1 & -1 & 1513 \\
12 & 0 & 0 & 0 & 3673 \\
13 & -1 & -1 & -1 & 1520 \\
14 & 0 & 0 & 0 & 3755 \\
15 & 1 & -1 & 1 & 3829 \\
16 & 0 & 0 & 0 & 4314 \\
17 & -1 & -1 & 1 & 4241 \\
18 & -1 & 1 & -1 & 450 \\
19 & 0 & 1.682 & 0 & 1713 \\
20 & 0 & 0 & -1.682 & 1957 \\
\hline
\end{tabular}

Fibrinolytic activity $(Y)=+3728.21+204.66 \mathrm{~A}-$ $509.50 \mathrm{~B}+927.80 \mathrm{C}+33.75 \mathrm{AB}-335.00 \mathrm{AC}+278.50 \mathrm{BC}-$ $344.06 A^{2}-377.65 B^{2}-200$.

Here, A-sucrose; B- $\mathrm{NaH}_{2} \mathrm{PO}_{4}$; C-moisture.

The model $F$ value of 10.74 implied that the model was significant. There is only a $0.05 \%$ chance that a "model $F$ value" this large could occur due to noise. Values of "Prob $>F$ " less than 0.05 indicated that the model terms were significant. In this model, the linear terms $\mathrm{B}$ and $\mathrm{C}(P<0.05)$ and quadratic terms $\mathrm{A}^{2}$ and $\mathrm{B}^{2}(P<0.05)$ were statistically significant (Table 5). The linear factor $A$, interaction terms $(\mathrm{AB}, \mathrm{AC}, \mathrm{BC})$, and quadratic term $\left(\mathrm{C}^{2}\right)$ were insignificant $(P>0.05)$. The "lack of fit $F$ value" of 2.85 implies the lack of fit is not significant relative to the pure error. There is a $13.75 \%$ chance that a "lack of fit $F$ value" this large could occur due to noise. Nonsignificant lack of fit is good. "Adequate precision" measures the signal (response) to noise (deviation) ratio. A ratio greater than 4 is desirable. In this model the ratio 12.729 indicates an adequate signal and therefore the model is significant for the enzyme bioprocess.

The goodness-of-fit of the model was checked by comparing the coefficient of determination $\left(R^{2}\right)$ with adjusted coefficient of determination $\left(R^{2}\right)$, which are measures of the amount of the reduction in the variability of response obtained by using the repressor variables in the model [35]. In this model, the coefficient of determination $\left(R^{2}\right)$ is 0.9063 and it explains $90.63 \%$ variability in the model and the adjusted $R^{2}$ was 0.82 . The $R^{2}$ value closer to 1.0 shows a stronger model with better predictability [36]. Figures 3(a)-3(c) depicted the $3 \mathrm{D}$ plot of the response from the interaction among variables and determined the optimum concentrations of each factor 
TABLE 5: ANOVA for response surface quadratic model.

\begin{tabular}{|c|c|c|c|c|c|}
\hline Source & Sum of squares & $\mathrm{df}$ & Mean square & $F$ Value & $P$ value \\
\hline Model & $2.109 E+007$ & 9 & $2.344 E+006$ & 10.74 & 0.0005 significant \\
\hline A-sucrose & $5.720 E+005$ & 1 & $5.720 E+005$ & 2.62 & 0.1365 \\
\hline $\mathrm{B}-\mathrm{NaH}_{2} \mathrm{PO}_{4}$ & $3.545 E+006$ & 1 & $5.545 E+006$ & 16.25 & 0.0024 \\
\hline C-moisture & $1.176 E+007$ & 1 & $1.176 E+007$ & 53.88 & $<0.0001$ \\
\hline $\mathrm{AB}$ & 9112.50 & 1 & 9112.50 & 0.042 & 0.8422 \\
\hline $\mathrm{AC}$ & $8.978 E+005$ & 1 & $8.978 E+005$ & 4.11 & 0.0700 \\
\hline $\mathrm{BC}$ & $6.205 E+005$ & 1 & $6.205 E+005$ & 2.84 & 0.1226 \\
\hline $\mathrm{A}^{2}$ & $1.706 E+006$ & 1 & $1.706 E+006$ & 7.82 & 0.0189 \\
\hline $\mathrm{B}^{2}$ & $2.055 E+006$ & 1 & $2.055 E+006$ & 9.42 & 0.0119 \\
\hline$C^{2}$ & $5.805 E+005$ & 1 & $5.805 E+005$ & 2.66 & 0.1339 \\
\hline Residual & $2.182 E+006$ & 10 & $2.182 E+005$ & & \\
\hline Lack of fit & $1.616 E+006$ & 5 & $3.232 E+005$ & 2.85 & 0.1373 not significant \\
\hline Pure error & $5.662 E+005$ & 5 & $1.132 E+005$ & & \\
\hline Cor total & $2.328 E+007$ & 19 & & & \\
\hline
\end{tabular}

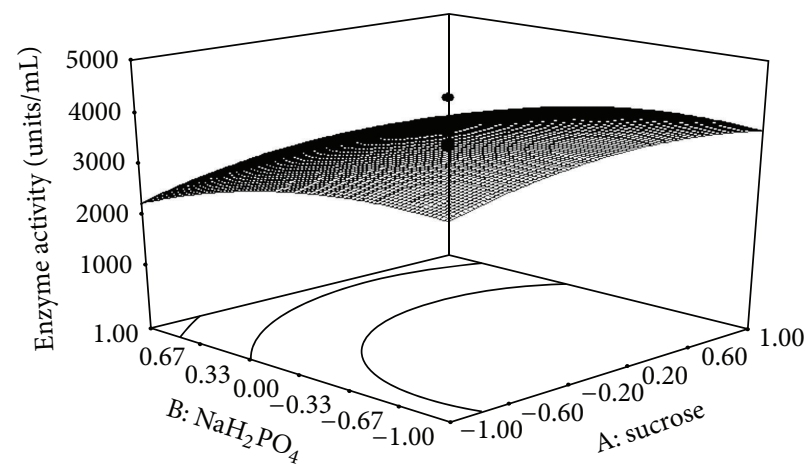

(a)

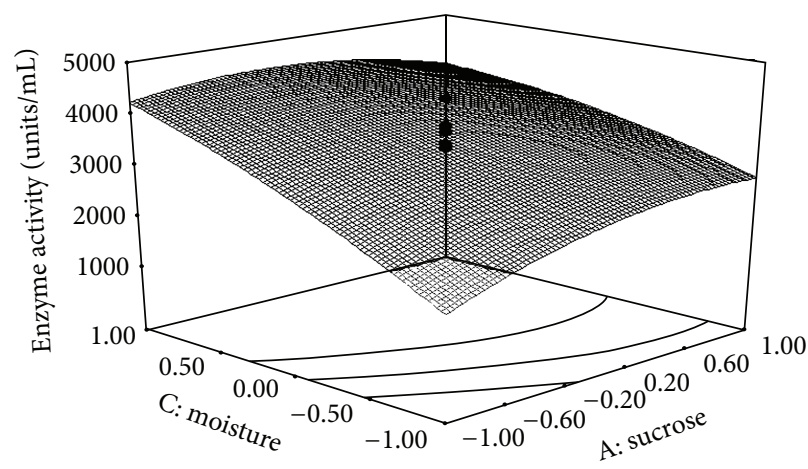

(b)

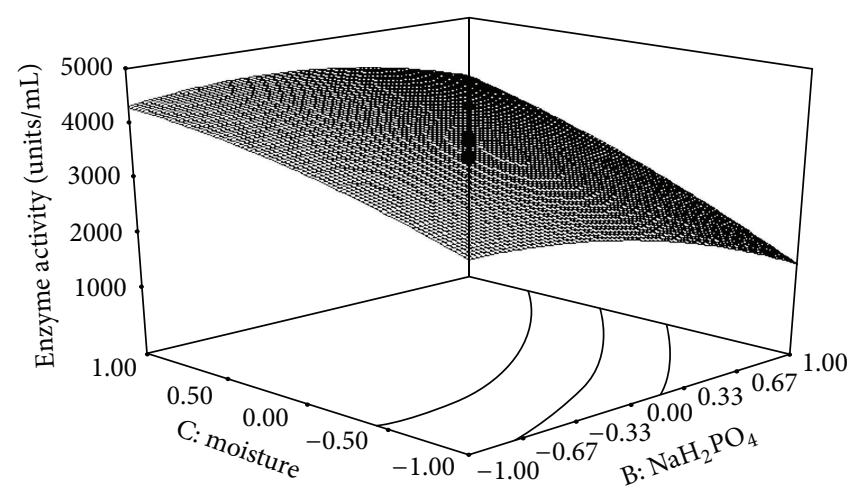

(c)

FIGURE 3: (a)-(c) Response surface plots showing the effect of interaction of sucrose and $\mathrm{NaH}_{2} \mathrm{PO}_{4}$ (a), sucrose and moisture (b), and moisture and $\mathrm{NaH}_{2} \mathrm{PO}_{4}(\mathrm{c})$.

for maximum fibrinolytic enzymes production by Paenibacillus sp. Fibrinolytic enzymes production varied significantly upon changing the initial concentrations of $\mathrm{NaH}_{2} \mathrm{PO}_{4}$ and moisture. The three-dimensional plots revealed that an increase in either moisture content of the medium, sucrose, or $\mathrm{NaH}_{2} \mathrm{PO}_{4}$ resulted in fibrinolytic enzymes production up to optimum level, whereas further increase in concentration decreased the enzyme yield. The perturbation plot (Figure 4) showed that moisture had a significant effect on fibrinolytic enzymes production compared to other variables. The fibrinolytic enzymes production were 4418 units $/ \mathrm{mL}$ in an optimized medium composed of (\%) sucrose (0.5), $\mathrm{NaH}_{2} \mathrm{PO}_{4}$ (0.075), and moisture (113.64). Results revealed that the RSM optimized medium increased 4.5 -fold of fibrinolytic enzymes production than the unoptimized medium. Fibrinolytic activities were comparatively higher than the earlier 


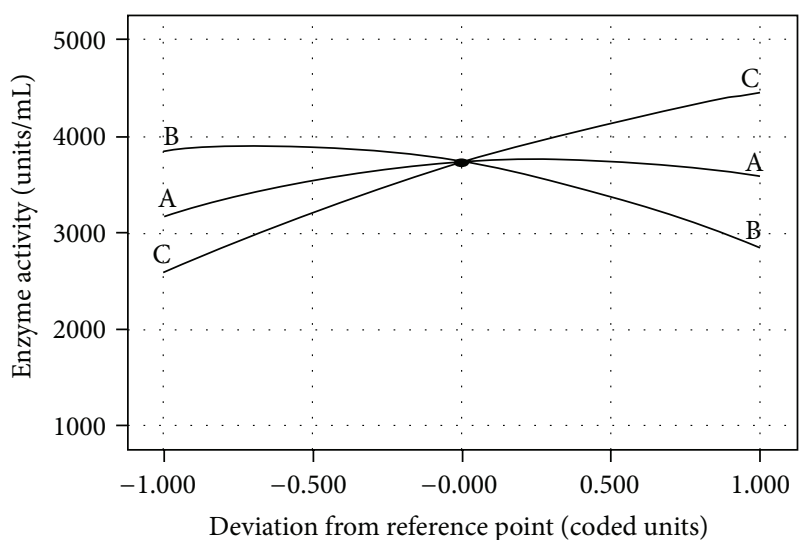

FIGURE 4: Perturbation graph summarizing the effect of sucrose (A), $\mathrm{NaH}_{2} \mathrm{PO}_{4}(\mathrm{~B})$, and moisture (C) on fibrinolytic enzymes production.

report of RSM on Bacillus subtilis [21] and on Bacillus sp. strain AS-S20-1 [37].

3.6. Validation of the Experimental Designs. To validate the model equation, experiments were carried out in triplicates for fibrinolytic enzymes production in optimized conditions predicted by the experimental model and the fibrinolytic enzymes production was found to be 4683 units $/ \mathrm{mL}$. The theoretical predicted response for the model equation was 4720 units $/ \mathrm{mL}$. The experimental result was very close to the predicted response which validated this model experimentally.

\section{Conclusion}

A Paenibacillus sp. IND8 shows enhanced production of fibrinolytic enzymes in statistically optimized medium. The optimized medium showed high fibrinolytic activities of 4418 units $/ \mathrm{mL}$, which is 4.5 -fold than that of the unoptimized medium. Purification and characterization of these fibrinolytic enzymes are in progress. This enzyme may be considered as a new source for thrombolytic agents.

\section{Conflict of Interests}

The authors declare that there is no conflict of interests regarding the publication of this paper.

\section{Acknowledgment}

The author Ponnuswamy Vijayaraghavan gratefully acknowledges the Council for Scientific and Industrial Research (CSIR), India, for providing a Senior Research Fellowship (ref. 09/652(0024)/2012 EMR-1).

\section{References}

[1] L. I. Moukhametova, R. B. Aisina, G. Y. Lomakina, and S. D. Varfolomeev, "Properties of the urokinase-type plasminogen activator modified with phenylglyoxal," Russian Journal of Bioorganic Chemistry, vol. 28, no. 4, pp. 278-283, 2002.
[2] F. Yan, J. Yan, W. Sun et al., “Thrombolytic effect of subtilisin QK on carrageenan induced thrombosis model in mice," Journal of Thrombosis and Thrombolysis, vol. 28, no. 4, pp. 444-448, 2009.

[3] J. Yuan, J. Yang, Z. Zhuang, Y. Yang, L. Lin, and S. Wang, "Thrombolytic effects of douchi fibrinolytic enzyme from Bacillus subtilis LD-8547 in vitro and in vivo," BMC Biotechnology, vol. 10, pp. 12-36, 2012.

[4] Y. Peng, X. Yang, and Y. Zhang, "Microbial fibrinolytic enzymes: an overview of source, production, properties, and thrombolytic activity in vivo," Applied Microbiology and Biotechnology, vol. 69, no. 2, pp. 126-132, 2005.

[5] H. Sumi, H. Hamada, H. Tsushima, H. Mihara, and H. Muraki, "A novel fibrinolytic enzyme (nattokinase) in the vegetable cheese natto; a typical and popular soybean food in the Japanese diet," Experientia, vol. 43, no. 10, pp. 1110-1111, 1987.

[6] H. Sumi, H. Hamada, K. Nakanishi, and H. Hiratani, "Enhancement of the fibrinolytic activity in plasma by oral administration of nattokinase," Acta Haematologica, vol. 84, no. 3, pp. 139-143, 1990.

[7] W. Kim, K. Choi, Y. Kim et al., "Purification and characterization of a fibrinolytic enzyme produced from Bacillus sp. strain CK 11-4 screened from Chungkook-Jang," Applied and Environmental Microbiology, vol. 62, no. 7, pp. 2482-2488, 1996.

[8] Y. Peng, Q. Huang, R.-H. Zhang, and Y.-Z. Zhang, "Purification and characterization of a fibrinolytic enzyme produced by Bacillus amyloliquefaciens DC- 4 screened from douchi, a traditional Chinese soybean food," Comparative Biochemistry and Physiology B, vol. 134, no. 1, pp. 45-52, 2003.

[9] J.-H. Seo and S.-P. Lee, "Production of fibrinolytic enzyme from soybean grits fermented by Bacillus firmus NA-1," Journal of Medicinal Food, vol. 7, no. 4, pp. 442-449, 2004.

[10] S. Sugimoto, T. Fujii, T. Morimiya, O. Johdo, and T. Nakamura, "The fibrinolytic activity of a novel protease derived from a Tempeh producing fungus, Fusarium sp. BLB," Bioscience, Biotechnology and Biochemistry, vol. 71, no. 9, pp. 2184-2189, 2007.

[11] C. Ash, F. G. Priest, and M. D. Collins, "Molecular identification of rRNA group 3 bacilli (Ash, Farrow, Wallbanks and Collins) using a PCR probe test," Antonie van Leeuwenhoek, vol. 64, no. 3-4, pp. 253-260, 1994.

[12] F. Lu, Z. Lu, X. Bie et al., "Purification and characterization of a novel anticoagulant and fibrinolytic enzyme produced by endophytic bacterium Paenibacillus polymyxa EJS-3," Thrombosis Research, vol. 126, no. 5, pp. e349-e355, 2010.

[13] S. Tao, L. Peng, L. Beihui, L. Deming, and L. Zuohu, "Solid state fermentation of rice chaff for fibrinolytic enzyme production by Fusarium oxysporum," Biotechnology Letters, vol. 19, no. 5, pp. 465-467, 1997.

[14] H.-S. Joo, C. G. Kumar, G.-C. Park, S. R. Paik, and C.-S. Chang, "Oxidant and SDS-stable alkaline protease from Bacillus clausii I-52: production and some properties," Journal of Applied Microbiology, vol. 95, no. 2, pp. 267-272, 2003.

[15] J. Lee, S. Park, W.-A. Choi et al., "Production of a fibrinolytic enzyme in bioreactor culture by Bacillus subtilis BK-17," Journal of Microbiology and Biotechnology, vol. 9, no. 4, pp. 443-449, 1999.

[16] L. Xiao-Lan, D. Lian-Xiang, L. Fu-Ping, Z. Xi-Qun, and X. Jing, "Purification and characterization of a novel fibrinolytic enzyme from Rhizopus chinensis 12," Applied Microbiology and Biotechnology, vol. 67, no. 2, pp. 209-214, 2005.

[17] D. C. Montogomery, Design and Analysis of Experiments, John Wiley \& Sons, New York, NY, USA, 5th edition, 2001. 
[18] R. H. Myers and D. C. Montogomery, Surface Methodology: Process and Product Optimization Using Designed Experiments, John Wiley \& Sons, New York, NY, USA, 2nd edition, 2002.

[19] X. Wang, L. Huang, Z. Kang, H. Buchenauer, and X. Gao, "Optimization of the fermentation process of actinomycete strain Hhs.015(T)," Journal of Biomedicine and Biotechnology, vol. 2010, Article ID 141876, 10 pages, 2010.

[20] M. A. Z. Coelho, G. C. Fontes, P. F. F. Amaral, and M. Nele, "Factorial design to optimize biosurfactant production by yarrowia lipolytica," Journal of Biomedicine and Biotechnology, vol. 2010, Article ID 821306, 8 pages, 2010.

[21] V. Deepak, K. Kalishwaralal, S. Ramkumarpandian, S. V. Babu, S. R. Senthilkumar, and G. Sangiliyandi, "Optimization of media composition for Nattokinase production by Bacillus subtilis using response surface methodology," Bioresource Technology, vol. 99, no. 17, pp. 8170-8174, 2008.

[22] T. Astrup and S. Müllertz, "The fibrin plate method for estimating fibrinolytic activity," Archives of Biochemistry and Biophysics, vol. 40, no. 2, pp. 346-351, 1952.

[23] S. F. Altschul, T. L. Madden, A. A. Schäffer et al., "Gapped BLAST and PSI-BLAST: a new generation of protein database search programs," Nucleic Acids Research, vol. 25, no. 17, pp. 3389-3402, 1997.

[24] J. H. Ko, J. P. Yan, L. Zhu, and Y. P. Qi, "Identification of two novel fibrinolytic enzymes from Bacillus subtilis QK02," Comparative Biochemistry and Physiology C, vol. 137, no. 1, pp. 65-74, 2004.

[25] P. Vijayaraghavan and S. G. P. Vincent, "Cow dung as a novel, inexpensive substrate for the production of a halo-tolerant alkaline protease by Halomonas sp. PV1 for eco-friendly applications," Biochemical Engineering Journal, vol. 69, pp. 57-60, 2012.

[26] Y. Mine, A. H. K. Wong, and B. Jiang, "Fibrinolytic enzymes in Asian traditional fermented foods," Food Research International, vol. 38, no. 3, pp. 243-250, 2005.

[27] P. Ellaiah, B. Srinivasulu, and K. Adinarayana, "A review on microbial alkaline proteases," Journal of Scientific and Industrial Research, vol. 61, no. 9, pp. 690-704, 2002.

[28] D. C. Montgomery, E. A. Peck, and G. G. Vining, Introduction to Linear Regression Analysis, John Wiley \& Sons, New York, NY, USA, 3rd edition, 2000.

[29] C.-T. Chang, M.-H. Fan, F.-C. Kuo, and H.-Y. Sung, "Potent fibrinolytic enzyme from a mutant of Bacillus subtilis IMRNK1," Journal of Agricultural and Food Chemistry, vol. 48, no. 8, pp. 3210-3216, 2000.

[30] B. K. Lonsane, N. P. Childyal, S. Budiatman, and S. V. Ramakrishna, "Engineering aspects of solid state fermentation," Enzyme and Microbial Technology, vol. 7, no. 6, pp. 258-265, 1985.

[31] R. S. Prakasham, C. S. Rao, and P. N. Sarma, "Green gram huskan inexpensive substrate for alkaline protease production by Bacillus sp. in solid-state fermentation," Bioresource Technology, vol. 97, no. 13, pp. 1449-1454, 2006.

[32] M. Hajji, A. Rebai, N. Gharsallah, and M. Nasri, "Optimization of alkaline protease production by Aspergillus clavatus ES1 in Mirabilis jalapa tuber powder using statistical experimental design," Applied Microbiology and Biotechnology, vol. 79, no. 6, pp. 915-923, 2008.

[33] M. Elibol, "Optimization of medium composition for actinorhodin production by Streptomyces coelicolor A3(2) with response surface methodology," Process Biochemistry, vol. 39, no. 9, pp. 1057-1062, 2004.
[34] A. Dean and D. Voss, Design and Analysis of Experiments, Springer, New Delhi, India, 2006.

[35] D. Ba and I. H. Boyaci, "Modeling and optimization I: usability of response surface methodology," Journal of Food Engineering, vol. 78, no. 3, pp. 836-845, 2007.

[36] P. D. Ha, "Statistical problem solving," in Experimental Design in Biotechnology, P. D. Haaland, Ed., pp. 1-18, Marcel Dekker, New York, NY, USA, 1989.

[37] A. K. Mukherjee and S. K. Rai, "A statistical approach for the enhanced production of alkaline protease showing fibrinolytic activity from a newly isolated Gram-negative Bacillus sp. strain AS-S20-I," New Biotechnology, vol. 28, no. 2, pp. 182-189, 2011. 

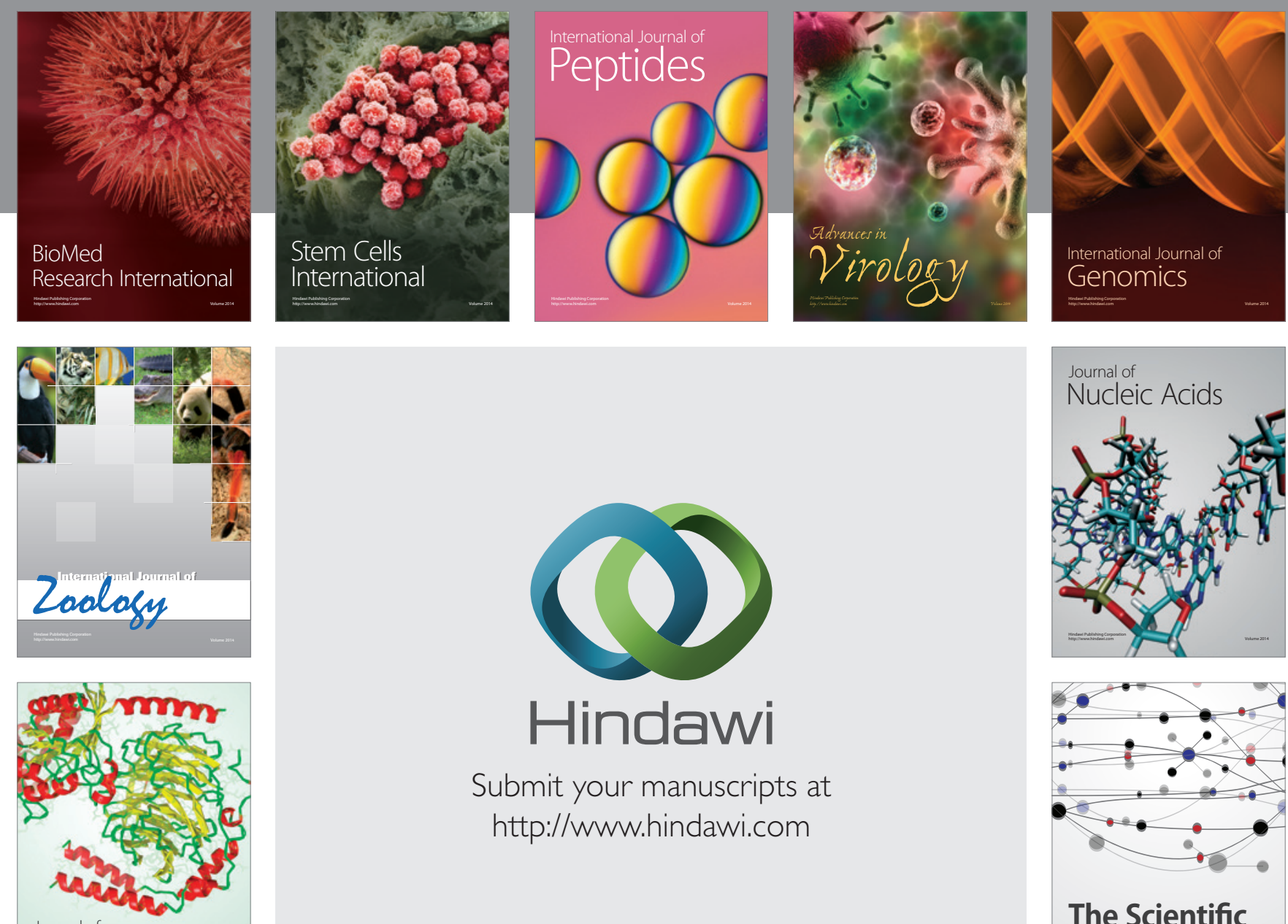

Submit your manuscripts at

http://www.hindawi.com

Journal of
Signal Transduction
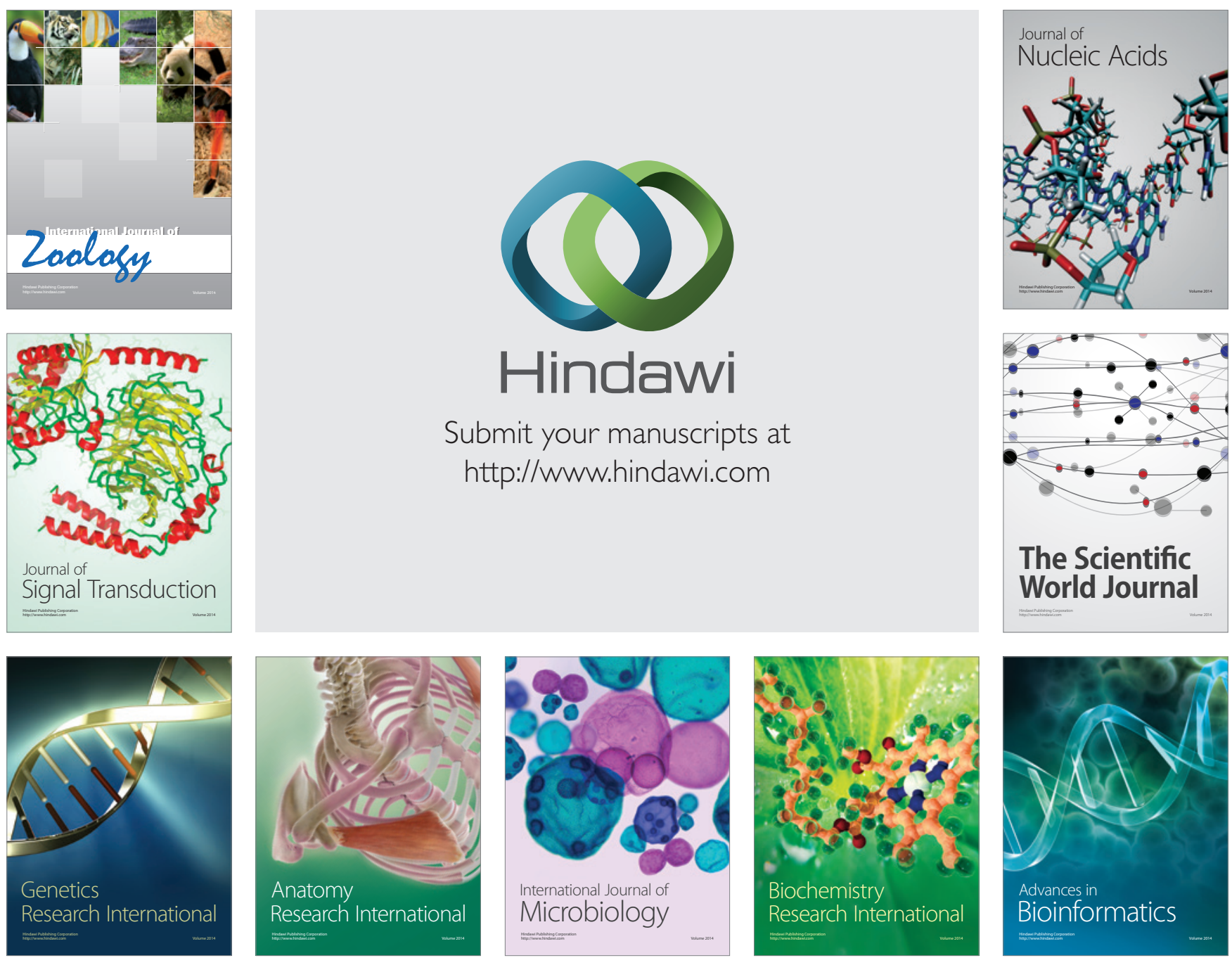

The Scientific World Journal
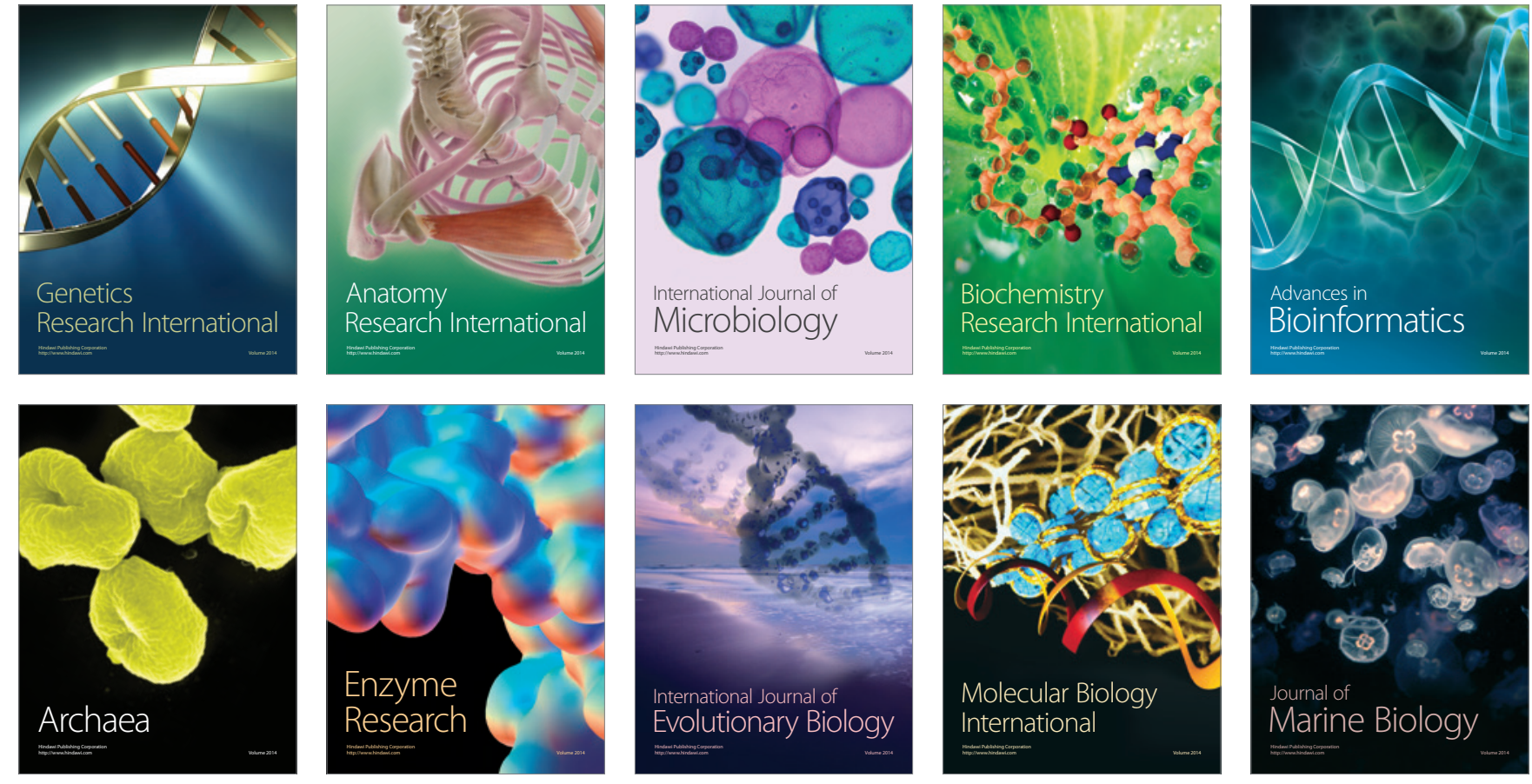